\title{
HONEYCOMB WEATHERING OF SANDSTONE OUTCROPS AT AL-HIJR (MADA'IN SALIH), SAUDI ARABIA
}

\author{
Saleh, M. \\ Assoc. Prof. Heritage Resources Management \& Tour Guidance dept., College of Tourism \& \\ Archaeology, King Saud Univ. Riyadh, Saudi Arabia \\ E-mail: mohsensaleh_22@yahoo.com
}

\begin{abstract}
In 2008 UNESCO proclaimed Mada'in Saleh as the first Saudi Arabia's world heritage site because of its rock-cut monumental tombs, with their elaborately ornamented façades, of the Nabataeans kingdom. The tombs sandstone outcrops are suffering from honeycomb weathering, which affected the rock surface. Salt weathering often results in the carving of the rock to give a honeycomb appearance. The initial spacing of the hollows may be resulted from the variations in the rock's properties, and weathering creates a roughening of the outcrops rock-cut tombs surface. The lower parts of the rock's surface are flaking of thin, multiple flakes due to salt weathering and repeat wetting and drying of the rock. To determine the mechanism of honeycomb formation at Al-Hijr archaeological site, sandstone samples have been investigated and analyzed by the following methods: field observations (visual examination), Optical Microscope (OM), Polarized Microscope (PM), Scanning Electron Microscope equipped with (SEM-EDS), and X-Ray Diffraction (XRD). The results declared that Al-Hijr sandstones samples have fine to large grained minerals (mono-crystalline and polycrystalline) that different in shape and size. The pore-filling cement is consisting mainly of clay minerals. XRD results revealed that Al-Hijr sandstones mainly composed of Quartz SiO2, Halite $\mathrm{NaCl}$ as a salt, Ringwoodite $\mathrm{Mg}_{2} \mathrm{SO}_{4}$ and Kaolinite $\mathrm{Al}_{2} \mathrm{Si}_{2} \mathrm{O}_{5}(\mathrm{OH})_{4}$. These results represent the correct diagnosis, which will help us to put the suitable strategy of the conservation.
\end{abstract}

Keywords: Al-Hijr, Rock-cut tombs, Honeycomb weathering, Investigations, Diagnosis

\section{Introduction}

Mada'in Salih is the largest Nabataeans site in the north of Saudi Arabia. It is situate roughly $500 \mathrm{~km}$ south-east of Petra, $400 \mathrm{~km}$ northwest of Medina and $22 \mathrm{~km}$ north of Al-Ula [1]. The limits of the core zone was identified by the following three points: North limit: $26^{\circ} 48^{\prime} 52^{\prime \prime} \mathrm{N}-37^{\circ} 55^{\prime} 51^{\prime \prime}$ E, East limit: $26^{\circ} 47^{\prime} 23^{\prime \prime} \mathrm{N}-37^{\circ} 58^{\prime} 17^{\prime}$ ' E, South limit: $26^{\circ} 46^{\prime} 09^{\prime \prime} \mathrm{N}-37^{\circ} 56^{\prime} 12^{\prime \prime} \mathrm{E}$. It is well known among scholars and travelers for its rock-cut monumental tombs similar to those in Petra [2]. The site lies in a large plain across which the Wadi Al-Ula runs from north-east to southwest. It was marked by a number of sandstone outcrops of various sizes and heights. The most impressive among them is Jabal Ithlib, north-east of the site, rising to almost $100 \mathrm{~m}$ above the 
surrounding plain [1]. Nabataeans settled in Al-Hijr between the second century $\mathrm{BC}$ and the second century AD. They left prominent antiquities in the form of magnificent rock cut tombs, praying places, settlement area, water reservoirs and irrigation system. During the early Islamic period, Al-Hijr was a main station on the pilgrimage route. A fort, water reservoir and a camp for the caravans were built for the service of the pilgrims. At the beginning of the $20^{\text {th }}$ century, Hegea station built on the Hejaz railway line was laid connecting AlMedina with Turkey via Syria. Al-Hijr site was spread on an area of $14.6 \mathrm{~km} 2$. Necropolis within the site, included several places and many of its tombs have local names such as; Qasr Al-Bint, Qasr Al-Fareed, Qasr Al-Sani, Al-Diwan ... etc., fig. (1). Alveolar or honeycomb weathering is a weathering phenomenon found in diverse environments throughout the world. It occurs on sandstones and other rock types in natural outcrops [3]. Honeycomb weathering is a term used to describe numerous small pits or alveolae, no more than a few centimeters wide and deep, separated by the intricate network of narrow walls and resembling a honeycomb [4] [5]. The term alveolar or honeycomb weathering was also used in the description of weathering forms of building stones, explained 'alveolar weathering' on building stones generally as 'relief in the form of closely spaced cavities (alveolae)' [6]. Several authors used the term for a more or less regular system of back-weathered holes and pits in building stone surfaces [7] [8] [9]. This paper sheds the light on honeycomb weathering, its mechanism of formation and its effect on the sandstone outcrops that rock-cut tombs were carved in.

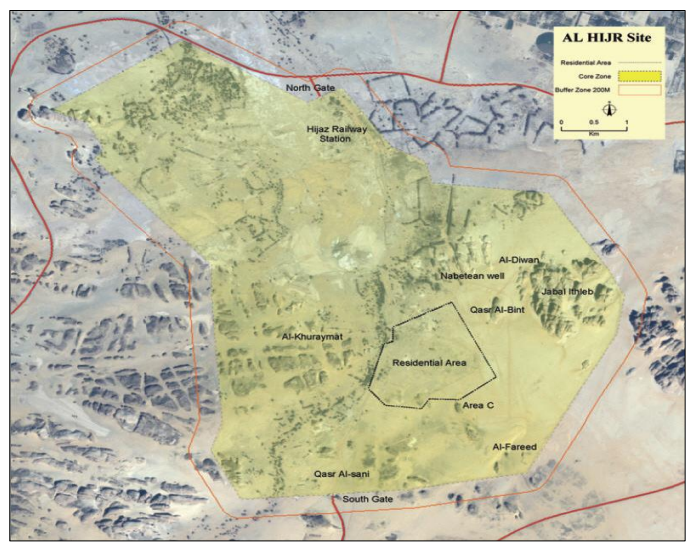

Figure (1) general view of Al-Hijr (Mada'in Salih), after Supreme Commission for Tourism Kingdom of Saudi Arabia 2007

\section{Materials and Methods}

Sandstone samples were collected to be examined and analyzed with the following methods: Optical Microscope (OM) Olympus $\mathrm{BX} 40 \mathrm{~F}-3$ in order to characterize the optical features, superficial shape and the grains size [10]. Polarized Microscope (PM) ZEISSAxioskop was used to determine the mineralogical composit-ion and the grain features by using many cross and thin sections samples [11] [12]. Scanning Electron Microscope (SEM) JEOL/EO, JSM-6380 device, equipped with an EDS link operating up to an accelerating voltage of $25 \mathrm{kV}$ and a working distance of $9 \mathrm{~mm}$ was used to investigate the morphology of the deteriorated surface of the sandstone samples [13] and to detect the distribution of the chemical elements on the sandstone samples. X-ray diffraction method (XRD) perform-ed with an Ultima IV, multipurpose X-ray diffraction system equipped with a copper anticathode. The measuring conditions were set as follows: $\mathrm{Cu}$ target, $40 \mathrm{kV}$ accelerating voltage, $40 \mathrm{~mA}$ 
current, the scanning range of $2 \theta$ was from 4 to $70^{\circ}$ and the scanning speed was $2 \%$ min. it was used to identify the

\section{Results}

\subsection{Field observations}

Through field observations of AlHijr (Mada'in Salih) site, it can be observed the following: The spread of the honeycomb phenomenon at Mada'in Salih sandstone outcrops differs in sizes and shapes, it is concentrating in the intermediate areas of the sandstone outcrops, fig. (2-a, b). The lower parts were suffering from severe erosion processes where the external parts of the rocky outcrop were loosed due to the multiple flaking process, fig. (3-a) and

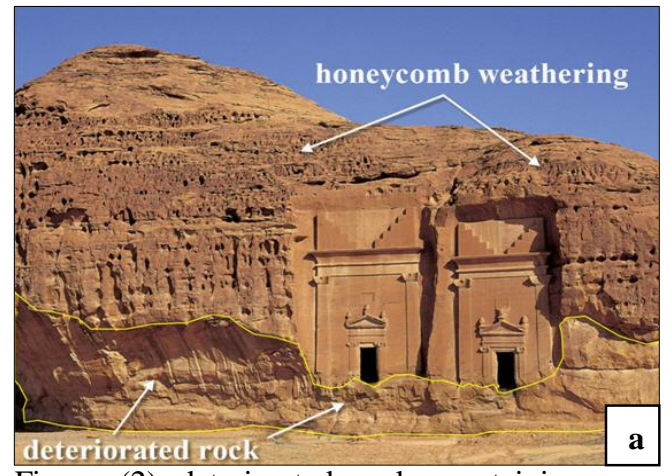

chemicals compositions [14] of sandstone samples.

the high amount of salts in the form of solid hard crusts up to $0.7 \mathrm{~cm}$ thick fig. (3-b). It was also noted that the effects of rain water and its destructive effect was evident in the light yellow to white grooves at the rock surface. This resulted in dissolving and decomposing of the rock composition. This effected on the places (grooves) often surrounded by red-brown veins looking like the roots of tree, while cobbles are often observed in the red-brown sandstones fig. (3-c).

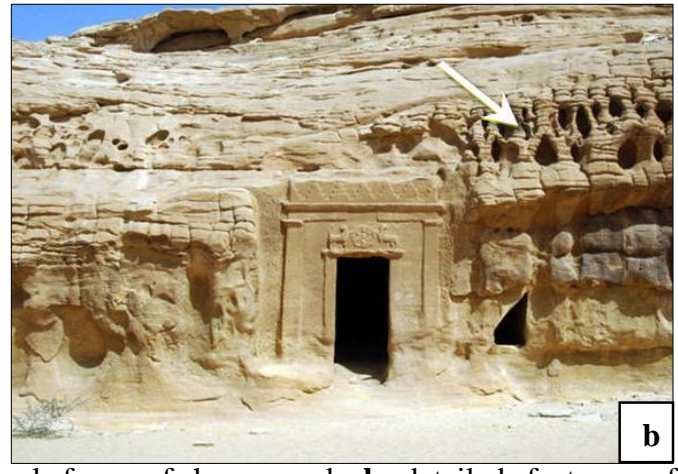
honeycomb weathering in the intermediate areas of the sandstone outcrops, Al-Hijr site.
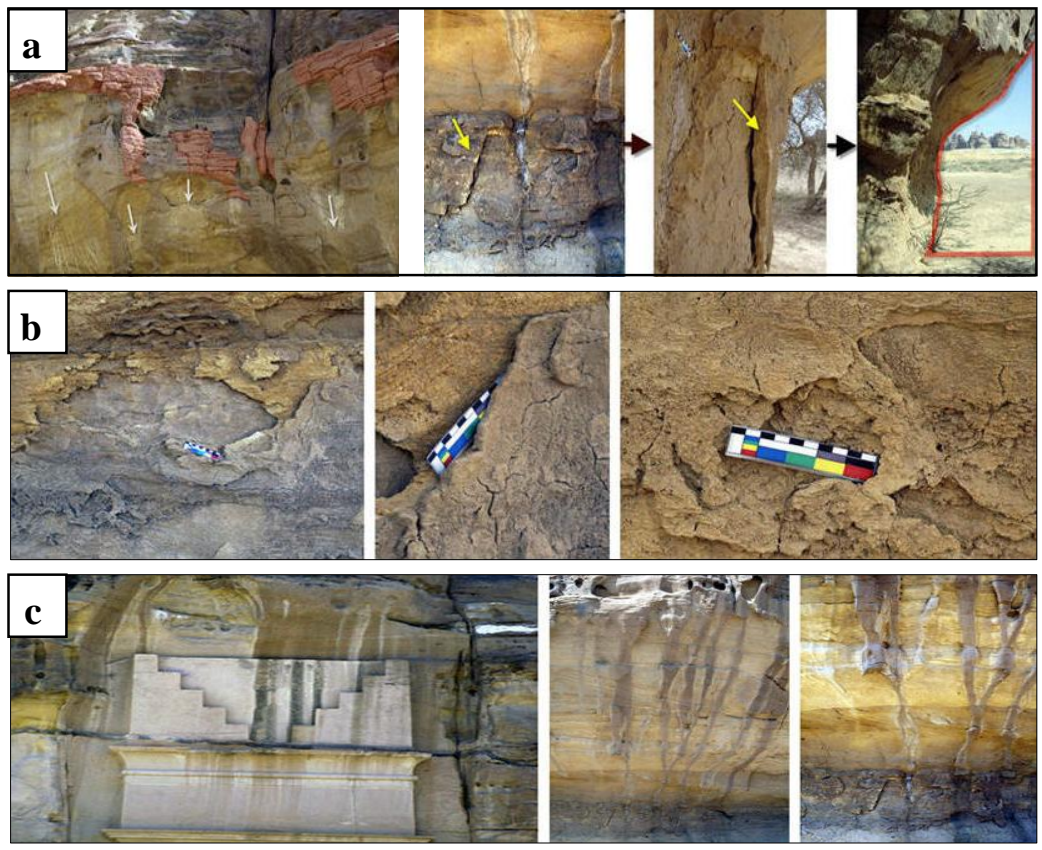

Figure (3) $\underline{\mathbf{a}}$ multiple flaking process, $\underline{\mathbf{b}}$ solid hard crusts of salt up to $0.7 \mathrm{~cm}$ thick, $\underline{\mathbf{c}}$, the dissolving and decomposing of rock by rain water 


\subsection{Optical microscope results.}

The investigation of sandstone samples with the optical microscope showed that they composed of fine to large grained minerals that are different in shape and size, with pore-filling cement mainly consisting of clay minerals and feldspar in addition to lime cluster, fig $(4-\mathrm{a}, \mathrm{b})[15]$.
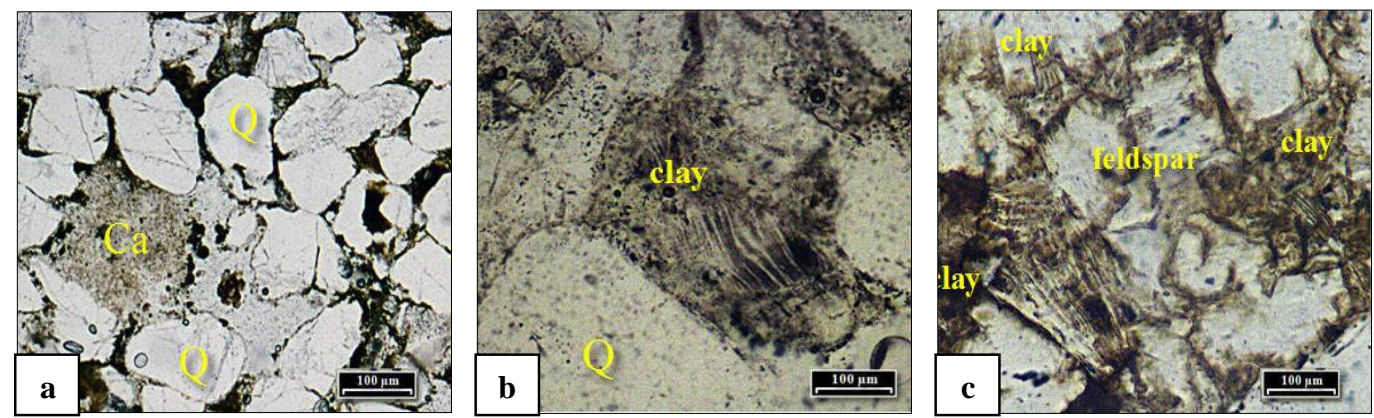

Figure (4) $\underline{\mathbf{a}}$ the main components of Al-Hijr sandstone, $\underline{\mathbf{b}} \& \underline{\mathbf{c}}$ the clay mineral and feldspar between the quartz grains.

\subsection{Polarized microscope results}

Polarized microscopy "PM" is used to identify the crystal texture, grain size, shape and the type of cementing material of the sandstone rock. Its examination showed that quartz is the shape and size of quartz grains. Monocrystalline and Polycry-stalline quartz grains were detected and feldspar, cluster of calcium and clay cement were main component and there is variety in also noticed, fig. (5-a, b) [5].
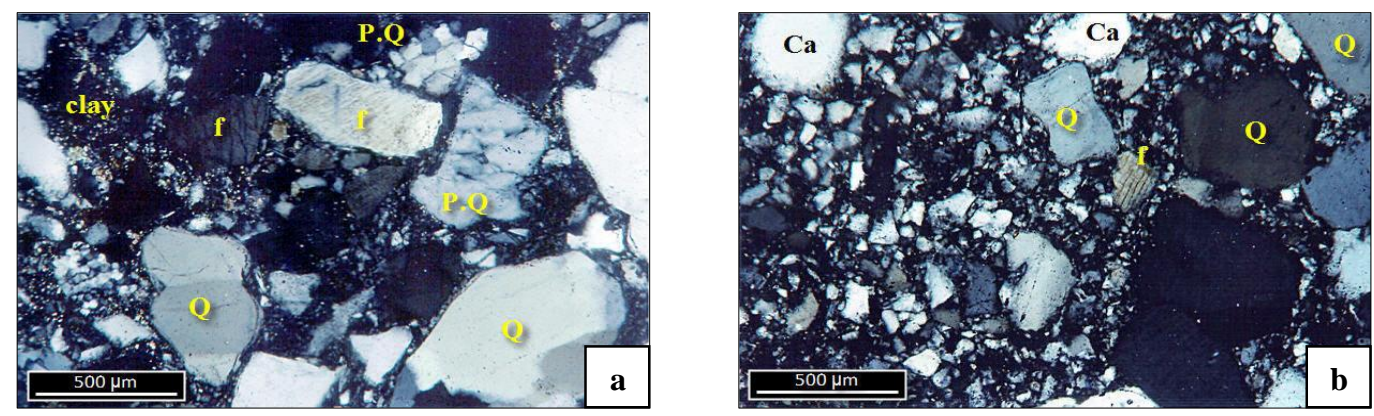

Figure (5) a variety in shape and size of quartz grains, Polycrystalline quartz grains (P.Q), $\underline{\mathbf{b}}$ the clay mineral, feldspar and lime (Ca) between the quartz grains.

\subsection{SEM investigation results}

Scanning electron microscope investigations showed that grains of quartz and feldspar (the latter showing signs of alteration) were surrounded by a clay matrix, fig. (6-a, b). Clay minerals have a flat shape like small flakes. These

flaked shapes are typical of Kaolinite [16]. Different spots of sandstone samples were investigated by EDS to identify their elemental composition, tab. (1).
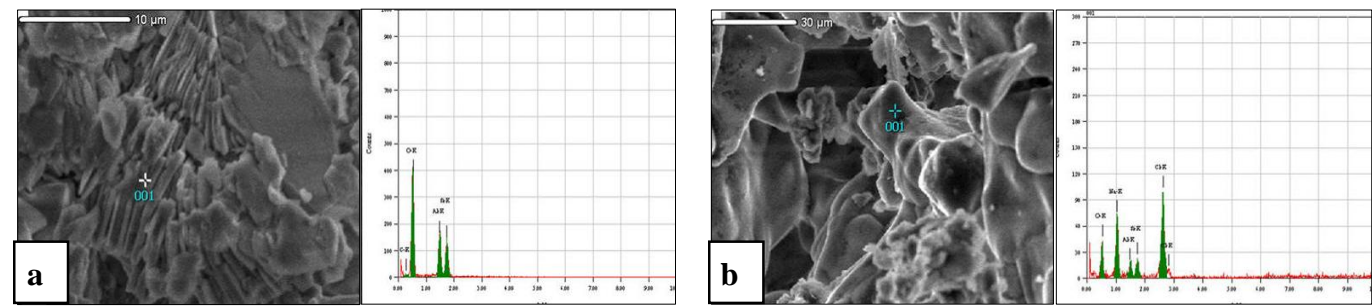

Figure (6) a SEM photomicrographs and EDS spectra of sandstone showing clay minerals flakes shapes, $\underline{\mathbf{b}}$ halite crystal between the quartz grains. 
Table (1) the elemental composition (wt. \%) of the studied sandstones samples

\begin{tabular}{|c|c|c|c|c|c|c|c|c|}
\hline Samples & $\boldsymbol{C}$ & $\boldsymbol{O}$ & $\boldsymbol{N a}$ & $\boldsymbol{A l}$ & $\boldsymbol{S i}$ & $\boldsymbol{C l}$ & $\boldsymbol{C a}$ \\
\hline $\mathbf{1}$ & 6.94 & 46.92 & - & 22.66 & 23.49 & - & - \\
\hline $\mathbf{2}$ & 5.26 & 47.94 & - & 21.55 & 25.25 & - & - \\
\hline $\mathbf{3}$ & - & 49.56 & 0.76 & 19.62 & 27.33 & 0.97 & 1.77 \\
\hline $\mathbf{4}$ & - & - & 0.98 & - & 22.82 & 5.45 & 31.74 \\
\hline $\mathbf{5}$ & - & 0.525 & 1.041 & 1.486 & 1.739 & 2.621 & - \\
\hline
\end{tabular}

\section{5. $X R D$ results}

Different sandstone samples The XRD analysis results were were selected and prepared to be detected as listed in tab. (2) and shown analyzed by the powder method [17]. in fig (7).

Table (2) the identified minerals of the stones and mortar samples by XRD analysis.

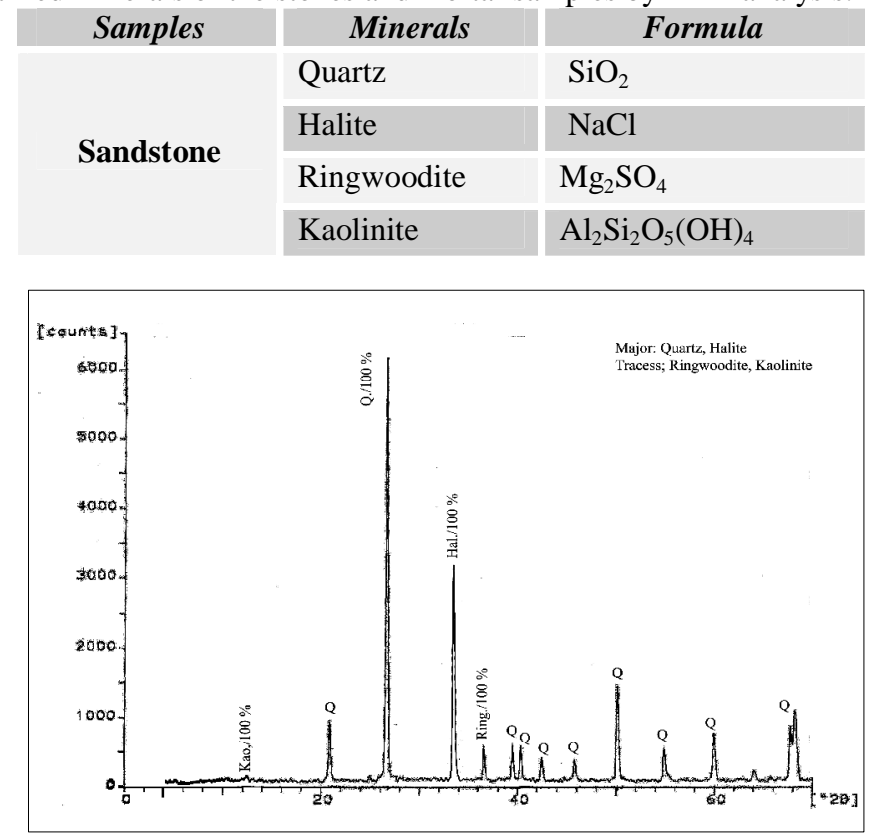

Figure (7) XRD pattern of the identified sandstone mineral phases.

\section{Discussion}

It should be noticed that the sandstones are not uniformly resistant and many layers are more subjected to erosion. The region of Mada'in Salih is arid with average rainfall below $50 \mathrm{~mm}$ per year (40 to $50 \%$ of the rain falls in winter and $30 \%$ in spring). The average annual temperature is $22^{\circ} \mathrm{C}, 12^{\circ} \mathrm{C}$ in winter and $30^{\circ} \mathrm{C}$ in summer [1]. Wind is one of the main agents of erosion in the area. Wind blowing mainly from the northwest is stronger in spring and at the beginning of the summer. Two main aspects should be considered regarding to honeycomb weathering of sandstones rocks; first is the influence of external factors such as climate, moisture, and salt availability, secondly is the intrinsic factors of the rock texture (homogeneity/heterogeneity) and the minerals composition of the sandstone rock. The investigations of the sandstones samples by OM, PM and SEM-EDS revealed that they have fine to large quartz grains (Mono-crystalline and Polycrystalline) different in shape and size. The polycrystalline quartz grains have sutured boundaries between the crystals. This is characteristic of quartz from a metamorphic source. Composite quartz from igneous sources usually has straighter crystal boundaries. The much finer sediment surrounds the composite quartz grains of mono- 
crystalline quartz. The pore-filling cement consists mainly of clay mineral and feldspar. The chemical weathering of feldspars may be rapid, producing micas and clay minerals. Therefore feldspars are most abundant and best preserved in rocks derived from mechanical weathering [18] [19]. SEMEDS investigations showed that the grains of quartz surrounded by a clay matrix. Clay minerals are appearing flat in shape that is typical of Kaolinite [20]. The EDS investigation results of the sandstone samples identify the elemental composition where, $\mathrm{Al}, \mathrm{Si}$ and $\mathrm{O}$ are representing clay minerals, $\mathrm{Na}$ and $\mathrm{Cl}$ representing halite salt, and $\mathrm{Ca}$ and $\mathrm{C}$ representing calcite (lime cluster). XRD results revealed that Al-Hijr sandstones mainly composed of Quartz $\mathrm{SiO}_{2}$ the main component of the rock, and Halite $\mathrm{NaCl}$ as a salt. Ringwoodite $\mathrm{Mg}_{2} \mathrm{SO}_{4}$ and Kaolinite $\mathrm{Al}_{2} \mathrm{Si}_{2} \mathrm{O}_{5}(\mathrm{OH})_{4}$ that considered as cementing matrix were detected as traces compounds. Deterioration caused by salt can occur from a variety of sources [21]. The soluble salt in porous stone can be spread into the stone by rain or ground water. As the water evaporates, salt re-crystallizes inside the rock. The salt crystals outgrowing the available space in the rock's pores exert pressure. This leads to a breakdown of the rock surface that often results in a loose powdery surface with a white appearance. The salty water in the weathering process seems to be the most important factor for honeycomb weathering. The wind might play a role in the initial formation of alveoli in saltloaded rocks; honeycomb formation is necessarily related to heterogeneities in rock texture. Alveole can be evolution from a small pit in the rock surface and solely by salt crystallization during wetting / drying cycles [5] [22] [23]. The main deterioration mechanism of the rock-cut monumental tombs at Al-Hijr is swelling and shrinking of the clay minerals that form the cement or the matrix of the sandstone. In the presence of humidity, all clay minerals that
Kaolinite includes, may be subjected to osmotic-type swelling processes if the pores in the rock contain an electrolyte in solution [16] [24]. Halite salt $\mathrm{NaCl}$ is one of the most effective electrolytes in osmotic swelling of clays. Figure (8) shows the processes of intra-crystalline and osmotic swelling in clays. Sandstone can absorb water to depths $1-2 \mathrm{~cm}$ inside the rock. This means that when rain falls directly on the rocks surface (winddriven rain), the first few centimeters of the rock may experience a volume increase as a result of the clays expansion. This creates an area of tension that results in development of fractures between the wet zone of the rock and the dry zone behind it. Swelling stresses lead to the development of scaling and flaking as well as contour-scaling [16]. Once the external wet layer has dried as a result of evaporation due to the action of the sun, temperature increase during the day, and evaporation accelerated by the effects of the wind, the clays contract causing the appearance of drying or retraction fractures perpendicular to the surface as observed all over the Al-Hijr rocks. Water, swelling clays, and halite salt $\mathrm{NaCl}$, together with the high degree of anisotropy of Al-Hijr rocks, all of them caused severe deterioration problems to the rock-cut monumental tombs. Once the rock starts to weather, it creates a hollow that in turn encourages further salt retention. This means that the salt weathering often results in the hollowing out of the rock to give a honeycomb appearance. The initial spacing of the hollows may be related to variations in rock properties and weathering creates a roughening of the rock surface. As weathering continues, small depressions either merge or become overwhelmed by adjacent hollows. Through this process of self-selection, collections of what appear to be optimally-sized honeycombs develop and can replace the majority surface of the rock. The hydration/dehydration behavior of magnesium sulphate is an additional factor 
that leads to damage and material loss in the developing alveolar holes. In addition to crystallization pressure, volume changes of this salt cause expansion and shrinking of the sandstone in the affected zone [5] [25], and accelerate the damage of the surface grain layers in the alveole. Since these processes are only dependent on the changing relative humidity of the air in the alveole and not on contact with

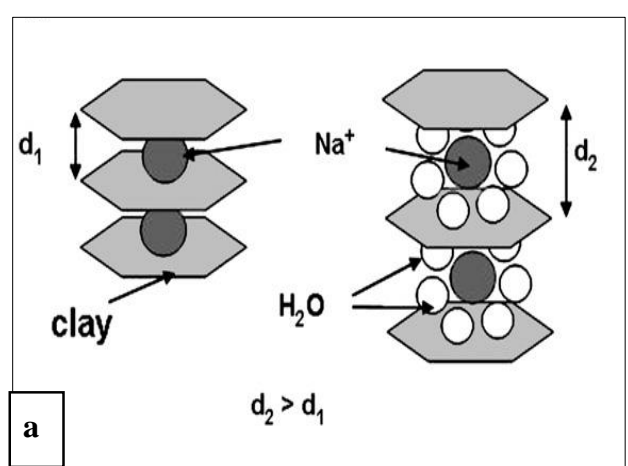

liquid water, they can work even in dry periods without rain events. Weathering is limited to the outermost grain layers at the bottom and on the walls of the alveole with extremely high salt concentrations, gradually moving deeper each time after loss of the surface material. Detached sand grains mixed with salts can be frequently detected at the bottom of alveole. Larger holes can finally coalesce, fig. (9) [26].

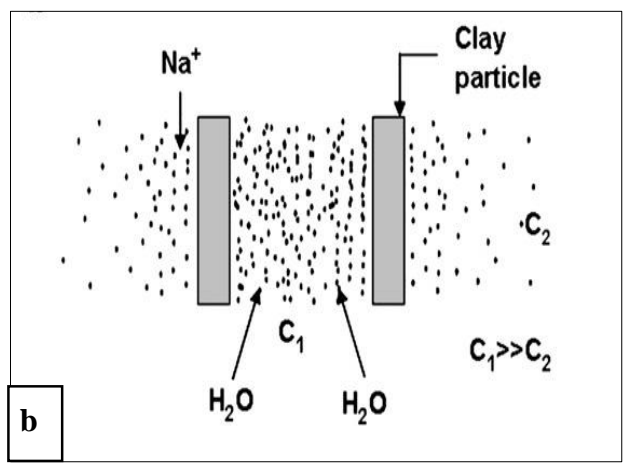

Figure (8) diagram of the processes of intracrystalline swelling $\underline{\mathbf{a}}$ osmotic swelling of the clays $\underline{\mathbf{b}}$ (basal spacing of the clays and concentration of $\mathrm{Na}$ ions (after Sebastian and others 2007)
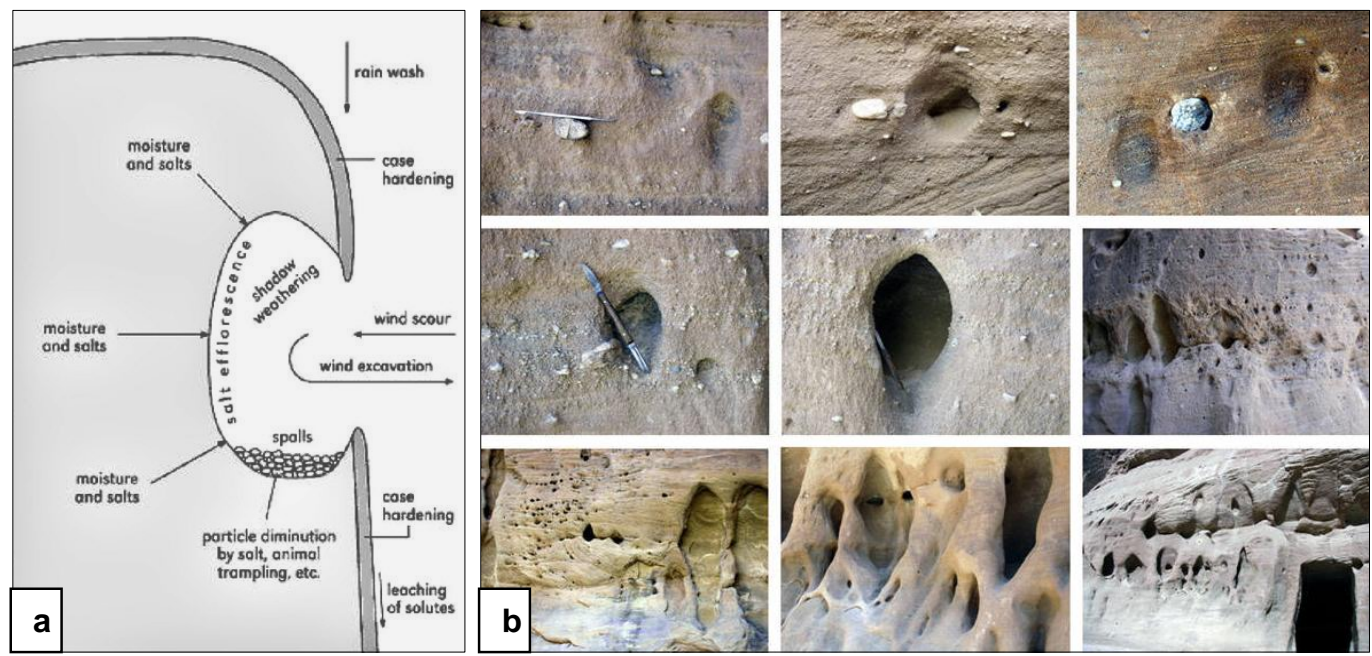

Figure (9) a the mechanism formation of honeycomb (after Angel Ginés and others 2009), $\underline{\mathbf{b}}$ different stages of honeycomb weathering at Al-Hijr archaeological site.

\section{Conclusions}

The interaction of the following variables, i.e. water, swelling clays and $\mathrm{NaCl}$, together with the high degree of anisotropy of these rock-cut monumental tombs, causes severe decay deterioration problems to the rock-cut monumental tombs. The most effective strategy for the conservation of this material would therefore be controlling these variables to minimize or prevent future damage to the rocks. This conservation strategy should include preventing the water from penetrating into the pores in the rock by implementing barriers (e.g. hydrophobic coatings), reducing the amount of $\mathrm{NaCl}$ in the pores for example by poulticing and increasing the mechanical resistance of the sandstone in areas of severe damage using suitable consolidants. The obtained results can be an important contribution to the study of sandstone's deterioration in historic buildings, and may facilitate the choice of the most suitable restoration method for the rock-cut monumental tombs. 


\section{References}

[1] Supreme Commission for Tourism Kingdom of Saudi Arabia, (2007). AL-HIJR archaeological site (Mâdain Sâlih) Riyadh, Saudi Arabia.

[2] Negev, A. \& Gibson, S., (2005). Archaeological encyclopedia of the Holy Land, Continuum International Publishing Group.

[3] Mustoe, E., (1982). The origin of honeycomb weathering, Geological Society of America Bulletin, Vol. 93, pp: 108-115.

[4] Huggett, R., (2007). Fundamentals of Geomorphology, Rutledge, New York

[5] Siedel, H., (2010). Alveolar weathering of Cretaceous building sandstones on monuments in Saxony, Germany, in: Přikryl, R. \& Török, A. (Eds.) Natural stone resources for historical monuments. Geological Society, London, Special publications, Vol. 333, pp: 11-23.

[6] Fitzner, B., Heinrichs, K. \& Kownatzki, R., (1995). Weathering forms-classification and mapping, in: Snethlage, R. (Ed.) Denkmalpflege und Naturwissenschaft. Natursteinkonservierung I. Ernst \& Sohn, Berlin, pp: 41-88.

[7] Quayle, N., (1992). Alveolar decay in stone-it's possible origin, in: Delgado Rodrigues, J., Henriques F. \& Jeremias F. (Eds.): Proceedings $7^{\text {th }}$ Int. Cong. on deterioration and conservation of stone, Laboratório Nacional de Engenharia Civil, Lisbon, Vol. 1, pp: 109-118.

[8] Livingstone, R., (1994). Influence of evaporate minerals on gypsum crusts and alveolar weathering, in: Fassina, V., Ott, H. \& Zezza, F. (Eds.) Proceedings $3^{\text {rd }}$ Int. Symp. on the conservation of monuments in the Mediterranean Basin, Venice, Italy, pp:101-107.

[9] Alessandrini, G., Bocci, A., Bugini, R., Emmi, D., Peruzzi, R. \& Realini, M., (1992). Stone materials of Noto (Siracusa) and their decay, in: Delgado Rodrigues, J., Henriques F. \& Jeremias F. (Eds.) Proceedings $7^{\text {th }}$
Int. Cong. on deterioration and conservation of stone, Laboratório Nacional de Engenharia Civil, Lisbon, Vol. 1, pp. 11-20.

[10] Nord. A. \& Tonner, K., (1991). Stone weathering, air pollution effects evidenced by chemical analysis, Riksantikvarieämbetet och Statens historiska museer, Stock-holm, Sweden

[11] Ali, H., Saleh, M. \& Poksinska, M., (2002). The use of polarized microscope in the study of the brick, mortar and plaster used in AlFoustat houses, old Cairo, Egypt, in: Ali, H. (Ed.) Conference and workshop on conservation and restoration, Faculty of Fine Arts, Minia Univ., pp:1-10.

[12] Liritzis, I., Sideris, C., Vafiadou, A. \& Mitsis, J., (2008). Mineralogical, Petrological and radioactivity aspects of some building material form Egyptian Old Kingdom monuments, Journal of Cultural Heritage, Vol. 9 (1), pp: 1-13.

[13] Ferretti, M., (1993). Scientific investigations of works of art, ICCROM, Rome, Italy

[14] Uda, M., (2004). In situ characterization of ancient plaster and pigments on tomb walls in Egypt using energy dispersive X-ray diffraction and fluorescence, Nuclear Instruments and Methods in Physics Research, B 226, pp: 75-82.

[15] Hutcheon, I. \& Desrocher, S., (2003). Silicate-carbonate reactions in sedimentary systems: fluid composition control and potential for generation of overpressure, in: Worden, R. \& Morad, S. (Eds.) Clay mineral cements in sandstones, Int. Assoc. Sedimentol. Spec. Publ. (2003) No. 34, pp: 161-176

[16] Sebastian, E., Cultrone, G., Benavente, D., Fernandez, L., Elert, K. \& Rodriguez-Navarro, C., (2008). Swelling damage in clay-rich sandstones used in the church of San Mateo in Tarifa (Spain), Journal of Cultural Heritage, Vol. 9 (1), pp: 6676. 
[17] Saleh, M., (2013). Characterization of Qarh's wall plasters, Al-Ulla, Saudi Arabia: A case study, IJCS, Vol. 4 (1), pp: 65-80.

[18] Adams, A., Mackenzie, W. \& Guilford, C., (1988). Atlas of sedimentary rocks under the microscope, Longman, England.

[19] Mackenzie, W. \& Adams, A., (1998). A colour atlas of rocks and minerals in thin section, Monsoon Publishing LTd., England.

[20] Gftze, J. \& Siedel, H., (2004). Microscopic scale characterization of ancient building sandstones from Saxony (Germany), Materials Characterization, Vol. 53, pp: 209-222.

[21] Ludovico-Marques, M. \& Chastre, C., (2012). Effect of salt crystallization ageing on the com-pressive behavior of sandstone blocks in historical buildings, Eng-ineering Failure Analysis, Vol. 26, pp: 247-257.

[22] Rodriguez-Navarro, C., Doehne, E. \& Sebastian, E., (1999). Origins of honeycomb weathering: The role of salt and wind, Geological Society of America Bulletin, Vol. 111 (8), pp: 1250-1255.

[24] Rodriguez-Navarro, C., Hansen, H., Sebastian, E \& Ginell, W., (1997). The role of clays in the decay of ancient Egyptian limestone sculptures, JAIC, Vol. 36, pp: 151163.

[25] Juling, H., Kirchner, D., Brüggerhoff, S., Linnow, K., Steiger, M., El Jarad, A. \& Gülker, G., (2004). Salt damage of porous materials: A combined theoretical and experimental approach, in: Kwiatkowski, D. \& Löfvendahl, R. (Eds.) $10^{\text {th }}$ Int. Cong. on deterioration and conservation of stone, ICOMOS, Stockholm Sweden, Vol. 1, pp: 187-194.

[26] Goudie, A., (2009). Cavernous weathering In: Ginés A., Knez M., Slabe T., Dreybrodt W. (Eds.) - Karst Rock Features: Karren Sculpturing. Ljubljana, ZRC Publishing, pp: 85-86 